\title{
Histopathological features of post-mortem pituitaries: A retrospective analysis
}

\author{
Francisco José Tortosa Vallecillos ${ }^{1 *}$, Santiago Ortiz Fernández ${ }^{2}$ \\ ${ }^{1} \mathrm{MD}$, specialist in Pathological Anatomy - Department of Pathology, Centro Hospitalar Lisboa Norte, Lisboa. Lecturer, Faculdade de Medicina, Universidade de Lisboa. PhD Student at the Department of Medicine, \\ Universitat Autònoma de Barcelona (UAB), Barcelona, Spain \\ ${ }^{2} \mathrm{MD}$, specialist in Pathological Anatomy - Department of Pathology, Centro Hospitalar Lisboa Norte, Lisboa. Lecturer, Faculdade de Medicina, Universidade de Lisboa, Lisbon, Portugal
}

Study conducted at Centro Hospitalar Lisboa Norte, EPE, Hospital de Santa Maria, Lisbon, Portugal

Article received: $3 / 5 / 2015$ Accepted for publication: 3/25/2015

*Correspondence: Serviço de Anatomia Patológica CHLN, EPE, Hospital de Santa Maria Address: Av. Prof. Egas Moniz Postal code: 1649-035 Lisboa - Portugal franciscotortosa.pathology@gmail.com

\section{SUMmARY}

Objective: As a result of the use of neuroimaging techniques, silent pituitary lesions are diagnosed more and more frequently; however, there are few published post-mortem studies about this gland. Incidence data of pituitary lesions are rare and in Portugal they are outdated or even non-existent. The aim of this study is to determine the prevalence of normal patterns and incidental post-mortem pituitary pathology at Centro Hospitalar Lisboa Norte, analyzing the associations with clinical data and assessing the clinical relevance of the findings.

Method: We reviewed retrospectively and histologically 167 pituitaries of a consecutive series of autopsies from the Department of Pathology of this centre. They were done between 2012 and 2014, and in all cases medical records were reviewed. The morphological patterns observed, were classified into three major groups: 1) Normal histological patterns and variants; 2) Infectious-inflammatory pathology, metabolic and vascular disorders; 3) Incidental primary proliferation and secondary to systemic diseases.

Results: The subjects included in this study were of all age groups (from 1 day to 91 years old), 71 were female and 96 male. Fifty-seven of these glands didn't show any alteration; 51 showed colloid cysts arising from Rathke cleft; 44 presented hyperplasia in adenohypophysis and we identified 20 adenomas in 19 glands (immunohistochemically, eight PRL-producing and five ACTH-producing tumors), ten of which associated with obesity, 11 to hypertension and six to diabetes mellitus. There were two cases with metastasis.

Conclusion: Subclinical pathology in our country is similar to that seen in other parts of the world, but at older ages.

Keywords: pathology, pituitary gland, autopsy.

\section{INTRODUCTION}

Studies on the incidence and prevalence of pituitary adenomas (PA) and related injuries have varied over time and depending on the population studied. These variations are related to advances in health including increased access to modern imaging studies and the increased number of specialists in endocrinology. As a result of the development and widespread use of neuroradiology imaging studies, namely computed tomography (CT) and magnetic resonance imaging (MRI), silent pituitary lesions are diagnosed increasingly often. ${ }^{1-3}$ In a recent review of autopsy and MRI studies, the estimated global prevalence of PA was $16.7 \% .{ }^{4}$ Recently it has been recognized that the prevalence of clinically diagnosed PA is 3.5 to 5 times more common than previously thought, according to a Belgian study that showed a prevalence of approximately 1 per 1,000 persons. $^{5}$

The management of pituitary pathology is complex and requires the recognition of many pathological entities. In autopsy series, the incidence of pituitary pathology lies between 3 and $27 \% .{ }^{6}$ Variants within normality and pituitary changes that do not lead to relevant clinical translation were described. In addition, there are pituitary lesions (hyperplasia, microadenomas, pituitary 
atrophy, etc.) that may go unnoticed for long periods of time or even fail to be diagnosed due to their limited clinical significance. The incidental discovery of PA has become a subject of growing interest. However, the frequency with which systemic diseases (granulomatous inflammation, metabolic processes, metastatic tumors, etc.) can affect secondarily the structure of this gland is not known. ${ }^{2,7,8}$

Data on incidence of PA in the population are scarce, and the series based on MRI and autopsies are discordant with the surgical series in tertiary centers. Since the prevalence of values in different ethnic groups or populations is unclear, further studies are needed community-based, defining the real burden of pituitary lesions in the usual clinical practice, as well as geographical differences.

In Portugal, data on pituitary disease are scarce, obsolete or non-existent, which means that the national health system lacks reliable and updated epidemiological data to ensure adequate resource allocation, proportional to the impact of such tumors in the community.

Most post-mortem studies were done in forensic autopsies and many of them recommended, due to the high frequency of occult pituitary lesions found, anatomical and clinical autopsy studies in order to evaluate the associated clinical features. ${ }^{9}$

The objective of this study is to determine the prevalence of normal patterns and incidental post-mortem pituitary pathology in a consecutive series of patients of Centro Hospitalar Lisboa Norte (CHLN) - the largest referral center in Portugal -, which includes Hospital Santa Maria and Hospital Pulido Valente in Lisbon, analyzing possible associations with the available clinical data and highlighting the medical relevance of the findings.

\section{Method}

For the preparation of this work, 167 pituitary glands of a consecutive series of autopsies conducted by the Pathological Anatomy Service of CHLN were studied retrospectively. Autopsies were conducted between 1/1/12 and $12 / 31 / 14$. Pediatric necropsies (newborns and children) were included.

In all cases examined, the corresponding medical records were reviewed, with analysis of the following variables: age, gender, reason for inclusion, personal medical history and causes of death, including in the case of neonatal autopsies, the study of the placenta.

During the autopsy, the pituitary stalk was cut as high as possible to leave the gland intact. The procedure involved opening the sellar diaphragm and fracturing the dorsum of the sella turcica, subsequently pushed to allow the gland to be removed intact. Immediately after extraction, the pituitary glands were fixed in $10 \%$ buffered formaldehyde for at least 24 hours and up to 72 hours. Subsequently, the glands were assessed macroscopically, weighed, measured, cut sagittally, and processed according to the usual technical procedures for fixing in paraffin blocks for a complete histological evaluation. Sections were cut at 2 micra for hematoxylin-eosin (H\&E) staining, 4 micra for reticulin staining (Gomori's method), and 2 micra for immunohistochemical study, if necessary. In the latter case, the glands were deparaffinized, subjected to antigen retrieval and incubated with individual antibodies directed against specific pituitary hormones or cellular proteins (Table 1).

\section{TABLE 1 Antibodies used, origin, dilution and clone.}

\begin{tabular}{llll} 
Antibody against & Origin & Dilution & Clone \\
\hline PRL & Dako & $1: 300$ & Polyclonal \\
\hline GH & Dako & $1: 400$ & Polyclonal \\
\hline ACTH & Dako & $1: 100$ & O2A3 \\
\hline FSH & Novocastra & $1: 25$ & INN-HFSH-60 \\
\hline Subunit-alpha & Novocastra & $1: 200$ & 4E12 \\
\hline TSH & Serotec & $1: 50$ & AHP523 \\
\hline Ki-67 & Dako & $1: 150$ & MIB-1 \\
\hline P53 & Novocastra & $1: 70$ & D07
\end{tabular}

PRL: prolactin; GH: growth hormone; $\mathrm{ACTH}$ : adrenocorticotropic hormone; $\mathrm{FSH}$ : follicle-stimulating hormone; TSH: thyroid-stimulating hormone.

The preparations were stained with $\mathrm{H} \& \mathrm{E}$ and reticulin, as well as pituitary hormones (PRL, GH, ACTH, FSH, subunit-alpha, and TSH) or Ki-67 (indicative of cell proliferation) and $p 53$ (tumor suppressor gene) where necessary. PAs found were sorted according to the 2004 version of the World Health Organization (WHO) classification of tumors of endocrine organs. ${ }^{10}$

Cases in which necropsy was partial and limited to the thoracic and/or abdominal cavity; cases in which the time elapsed from death to completion of the examination was over 24 hours; and those cases in which the corpse was in poor conditions, and the glands showed evidence of autolysis were not included in this study.

We defined as pituitary incidentalomas all unexpected pituitary sellar lesions found during the necropsy due to any unrelated reason. This definition excludes subjects who experienced symptoms described as typical for PA, including visual changes and syndromes of defective or excessive pituitary hormone secretion.

Based on the findings, since the differential diagnosis of presumably asymptomatic lesions is quite broad, 
the observed morphological patterns were classified into three groups:

1. Histologically normal patterns and variants (developmental anomalies and cystic lesions);

2. Infectious-inflammatory disease, metabolic disorders and vascular disorders;

3. Incidental primary proliferation and secondary to systemic diseases.

\section{Results}

Gender distribution was 71 (42.5\%) females and 96 (57.5\%) males, with 153 corpses of white race and 14 colored. Age ranged between 1 day and 91 years; $22.8 \%$ of the autopsies were conducted on subjects between 70 and 79 years old (Chart 1). All autopsies derived from the different Services offered at the CHLN.

\section{Histologically normal patterns and variants}

Fifty-seven (34.1\%) of the glands examined showed no histologic abnormalities with possible pathological significance, 20 of which (out of 24) accounted for autop- sies in individuals under 18 years. Considering only adult glands (aged between 18 and 65 years), the average weight after fixation was $0.74+/-0.25 \mathrm{~g}$, and the average size of their longest axis was $13.94+/-1.72 \mathrm{~mm}$.

Fifty-one of the 167 glands studied (30.5\%) had colloid cysts derived from Rathke's cleft. In all cases, the cysts were located in the intermediate lobe; in two subjects, they were also located in the pars tuberalis. These were single cysts (in 11 of the glands) or, more frequently, multiple (40 cases; 78.4\%) small cysts between less than 1 and $9 \mathrm{~mm}$.

Three percent of the glands studied (five cases) had inframillimetric foci of squamous metaplasia with glandular remnants. They were observed in groups, mainly in the pituitary stalk and, less often, in the pars tuberalis.

In 23 of the 167 cases (13.8\%), rows of basophil endocrine cells immunohistochemically positive for ACTH were observed extending from the interface of the anterior and posterior lobes to the depth of the neurohypophysis. All cases were related to individuals older than 50 years (except for the gland of a 23 years old subject).

Herring bodies were also found in the neurohypophysis of two males (73 and 82 years old).

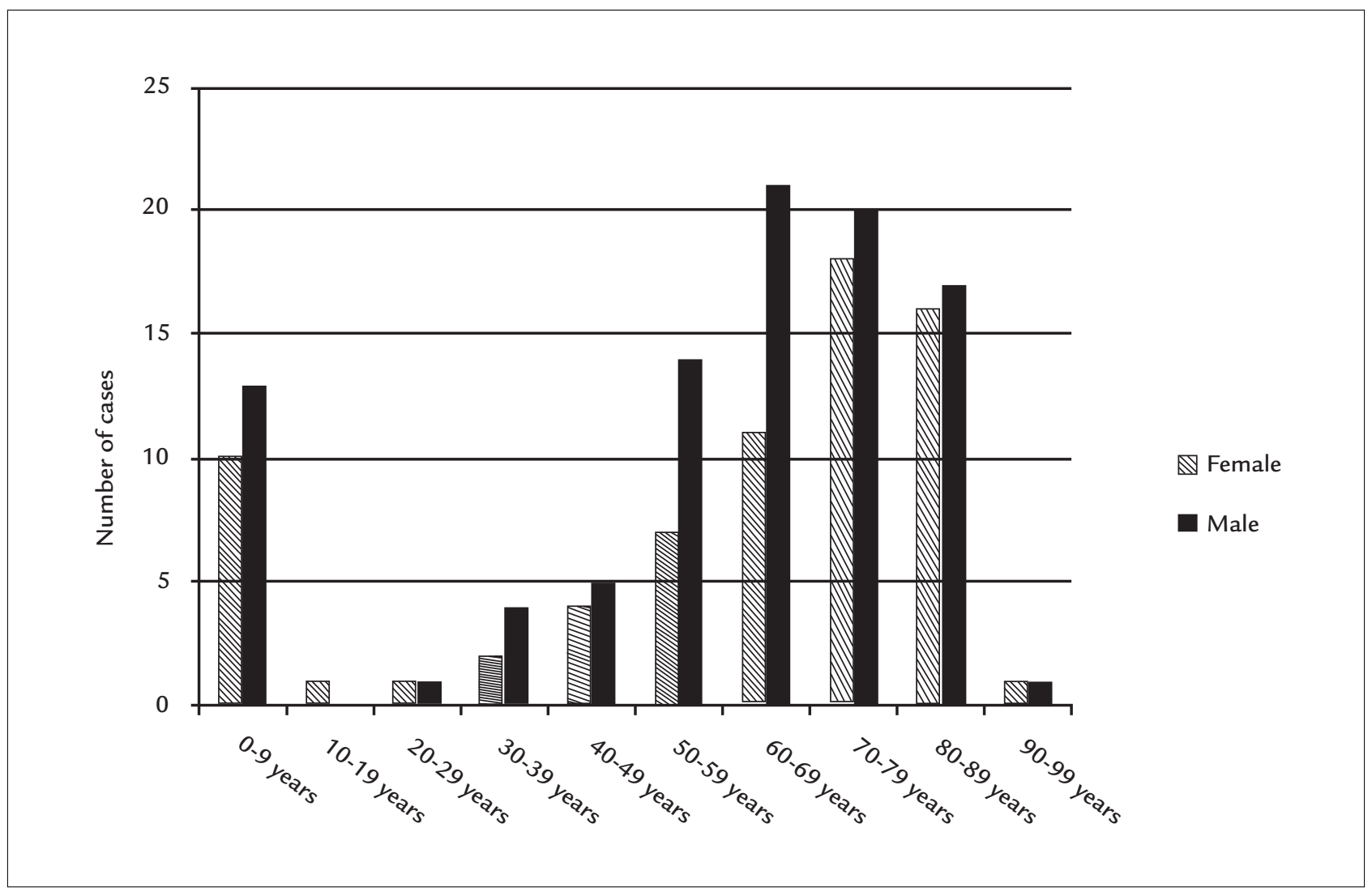

CHART 1 Distribution of the number of autopsies by gender and age range. 
In one gland in this series, we observed a concentric arrangement of unmyelinated nerve fibers comprising the neurohypophysis, which gave it a nodular appearance that reminded schwannomas ("nodular" neurohypophysis). It measured $1 \mathrm{~mm}$ and was located at the interface of the pars nervosa up to the infundibulum; there was no association with cellular pleomorphism, anisokaryosis, mitosis or other changes.

The cells in the neurohypophysis had granular transformation in three subjects, one female and two males, aged 62-78 years, one with amyloidosis and two with chronic renal failure $(\mathrm{CRF})$.

None of the autopsies performed revealed atrophy or flattening of the pituitary gland similar to that described in empty sella syndrome (intrasellar arachnoidocele that occurs as a result of a change in the diaphragm), ${ }^{11,12}$ and no cases of pan-hypopituitarism was found in the review of clinical histories.

None of the findings correlated with clinical symptoms that were mentioned in the medical history.

\section{Infectious-inflammatory disease, metabolic disorders and vascular} disorders

The presence of isolated lymphocytic foci within the adenohypophysis was a finding found in six of 167 autopsies (3.6\%). In these cases, the subjects were between 61 and 90 years old (except for a patient aged 39 years), and lymphocytes were mature and positioned as isolated cells, not causing destruction of the gland. Autoimmune or lymphoproliferative diseases were not constant.

There was nonspecific chronic inflammation in two newborns whose placentas revealed infection and hypoxemia, and in a 70-year-old with a history of epilepsy and meningitis. There was also an active chronic periglandular inflammatory infiltrate in a 75-year-old who died due to complications of a flu-like illness.

The presence of intracellular deposits of pigment in the neurohypophysis was a relatively common finding (six of 167 autopsies). They are dispersed in the parenchyma and were associated in two cases with cerebrovascular accident (stroke) and hemolysis; in other cases, no relationship was found.

We must highlight the incidence of pituitary vascular disease in this series of clinical autopsies (3\%); five of the examined glands had ischemic strokes. Age ranged between 41 and 82 years. In all cases, the review of the patients' medical history showed vascular risk factors such as high blood pressure (hypertension), diabetes mellitus (DM) or stroke, and more.
The presence of benign vascular proliferations was not observed in any of the 167 cases.

Incidental primary proliferation and secondary to systemic diseases

Forty-four of the studied pituitary glands (26.3\%) showed adenohypophysis hyperplasia, with expansion of the acini demonstrated by reticulin histochemical staining. In some cases there was a focal pattern, and in others a diffuse pattern, involving one or more cell types. Sixteen of the affected subjects were women and $28 \mathrm{men}$. Age ranged from 23 to 91 years. Considering only the glands of adults (aged 18 to 65 years), the mean size after fixation was $14.69+/-2.02 \mathrm{~mm}$, which implies a slight increase with respect to the average normal pituitary.

Since we did not find in the clinical histories of patients whose pituitary glands had hyperplasia any data that could be related to etiology, these cases were considered as asymptomatic or incidental idiopathic hyperplasia.

Twenty "typical" PAs were found in 19 subjects (one gland with two tumors), all smaller than $10 \mathrm{~mm}$ (microadenomas). Nine subjects were female (12.7\% of the total cases in females) and 11 male (11.5\% of the total males). Age ranged from 10 to 88 years, with 14 cases (70\%) between the $7^{\text {th }}$ and $9^{\text {th }}$ decades of life. Immunohistochemically, four were PRL-producing tumors, two $\mathrm{PRL} / \mathrm{GH}$, one PRL/GH/FSH, one PRL/GH/TSH, one $\mathrm{GH} / \mathrm{TSH}$, five ACTH (one of which with pituitary apoplexy), one FSH, three plurihormonal tumors, and two null-cell. Clinically, 10 cases were associated with obesity (one morbid), 11 HBP and six DM; there were no cases associated with hypo- or hyperthyroidism. Atypical cases of PA or primary pituitary carcinomas were not identified.

The PAs were not large enough to produce clinical symptoms. After the clinical histories were reviewed, none of the patients with lesions described had information pointing to compressive, visual or endocrine symptoms that could be related to the pathologic findings.

Of 25 autopsies with malignancies in various organs and tissues (two lung, two kidney, three bladder, two prostate, four colon, two sarcomas, one oligodendroglioma, two lymphocytic lymphoma/chronic lymphocytic leukemia - LL/CLL -, one multiple myeloma - MM -, one intravascular lymphoma, one myeloblastic leukemia, and four tumors of unknown origin), two cases presented metastatic infiltration of the pituitary gland (one LL/CLL and one small cell lung carcinoma). 


\section{Discussion}

Keep in mind that the collection of data from the 167 subjects was retrospective, and clinicopathological correlation is based on data previously collected on clinical history. Thus, it is possible that this was not an accurate and comprehensive reflection of the patient's situation, or that the pituitary disease generated symptoms that were not so relevant within the context of morbidity, which implies a limitation to this study.

We must also consider that the sample size does not allow for statistical significance necessary to some of the findings, and that we can only assume the trends. Nevertheless, interest is still great since these data derive from a series of anatomical and clinical autopsies.

Since the pediatric population is included, as well as a wide range of subjects of different age groups, we consider this a representative sample of the general population.

Within the patterns of histological normality and variants, our study showed in normal pituitary glands: colloid cysts, foci of squamous metaplasia, rows of endocrine cells in the neurohypophysis, Herring bodies, nodular transformation of the neurohypophysis and modification of its cells, adopting aspect of granular cells similar to those observed in other organs.

Colloid cysts are relatively frequent, small and asymptomatic. These remnants of Rathke's cleft are common incidental findings in autopsies. Studies in normal pituitary gland demonstrated that they appear in $32 \%$ of cas$\mathrm{es}^{13}$ (30.5\% in our series); of these, $80 \%$ (100\% in our series) were located in the intermediate lobe and the other in pars tuberalis.

Sometimes, the cysts are large enough to produce symptoms due to compression of the pituitary gland, optic chiasm and hypothalamus. ${ }^{14}$ Sometimes the infection of a cyst can cause the formation of abscesses. ${ }^{15}$ These cysts are benign and usually heal after they are excised. ${ }^{16}$ Subjects who undergo partial excision and drainage may have recurrences.

Squamous metaplasia of glandular remains is an adaptive process that appears with some frequency ( $3 \%$ in our series). Sometimes it leads to the formation of cysts large enough to produce symptoms ${ }^{17}$ which are primarily visual. Resection is often incomplete since it can affect vital structures, but relapse occurs very slowly over the years. Malignant transformation to squamous cell carcinoma is rare, but can occur. ${ }^{18}$

The presence of rows of ACTH-immunoreactive basophil cells in the posterior pituitary ("basophil invasion") is an age-related finding not customarily associated with endocrinopathies.
Sometimes it is possible to discern using H\&E in the neurohypophysis swollen axons that store oxytocin or vasopressin, with eosinophilic fibrillar appearance, which are called Herring bodies or neurosecretory bodies and constitute a normal finding.

Aggregates of polygonal cells with granular cytoplasm in the neurohypophysis or infundibulum are incidental findings at autopsy. ${ }^{19}$ They are usually asymptomatic but, if they grow, they can compress the gland, the optic chiasm or the hypothalamus.

Not often, infectious-inflammatory disease, metabolic disorders and vascular disorders can occur, which may affect the primary or secondary structure of this gland. In our study, we highlight the presence of isolated lymphocytic foci, nonspecific inflammation, ferric pigment deposits in the posterior pituitary, and some ischemic strokes.

Occasionally, a small number of lymphocytes can be seen on the interface between the anterior and posterior lobes of the pituitary ${ }^{20}$ Histologically, the cells are easily distinguished from the extensive and destructive infiltration observed in lymphocytic hypophysitis. Microfoci of lymphocytes have no clinical significance. Lymphocytic hypophysitis, by contrast, is a well-described inflammatory process, ${ }^{21}$ which can resemble PAs clinically and radiologically. Approximately $80 \%$ of cases occur in pregnancy, mostly postpartum, and they are characterized by total or partial pituitary insufficiency due to an autoimmune process, ${ }^{22}$ with men affected on rare occasions.

The presence of intracellular deposits of ferric pigment in macrophages of the neurohypophysis (confirmed in our series by histochemical study using Perls staining) was a relatively common finding (observed in six of 167 autopsies). These deposits seem to indicate minor bleeding similar to those that occur in other organs during small coagulation disorders, hypersideremia or mild local trauma. ${ }^{7}$ We did not find in our study a possible association between some sort of specific pathology and the presence of such deposits. Given our sample size, it is difficult to know whether this is a significant finding or if it is caused by chance.

In our study, the five subjects with ischemic infarcts also had risk factors (obesity, HBP, DM and/or stroke). Age range was wide, between 41 and 82 years, although three of these five subjects (60\%) were relatively young (41, 43 and 56 years old). However, it is noted that for clinical endocrine symptoms to appear, pituitary destruction must be greater than $50 \%{ }^{23}$ 
As for pituitary incidental primary proliferation and secondary to systemic diseases, we point out the occurrence of hyperplasia, adenomas and metastases.

Although in the past it was believed that the focal hyperplasia did not occur in the pituitary gland, currently there is no doubt that it exists and that it may even appear clinically and biochemically. ${ }^{24,25}$ In this series, acinar hyperplasia was observed in 44 of the 167 pituitary glands. The medical history of these subjects did not include information (either clinical or biochemical) that could be connected to the etiology of hyperplasia. While hyperplasia is a well-described phenomenon, there are still questions that remain without clear answer: Are all forms of hyperplasia primary or they result from hypothalamic changes? Are these cellular adaptation processes leading to adenomas? Are hyperplastic cells more prone to malignant transformation? What are the molecular mechanisms related to this hyperplasia? ${ }^{26,27}$ The predominance of males ( $63.6 \%$ of cases) in our series stands out, contrary to what is classically described for adenomas.

PAs comprise $10-20 \%$ of all intracranial tumors. ${ }^{4}$ They affect mainly women between the $3^{\text {rd }}$ and $6^{\text {th }}$ decade, but can occur in any age group..$^{28,29}$ Small incidental adenomas can occur with a probability of $20 \%$ in pituitary glands examined at autopsy. ${ }^{30,31}$

The incidence of adenomas in this study is consistent with that found in other series. Twenty adenomas (12.1\%) were found; other studies ${ }^{4,32}$ show incidences at $10-20 \%$. Coinciding with the classically described in the literature, women were slightly more affected than men. In our study series, ages ranged from 30 to 88 years (except for a 10 year old child), with 14 cases between the $7^{\text {th }}$ and $9^{\text {th }}$ decades of life, slightly higher than that found in other reviews. ${ }^{1,8,30}$ The most frequently found adenomas are prolactinomas. ${ }^{30,32,33}$ In our series, of the 20 PAs founds, four were PRL-producing tumors, other four cases were $\mathrm{PRL} / \mathrm{GH}$, and five corresponded to ACTHproducing adenomas. If we compare these data with the analysis of the surgical series held between 2004 and 2013 in the same hospital, in which 220 PAs were analyzed, we observe a prevalence of adenomas positive for GH (60) and FSH (59), followed by ACTH-producing tumors (44). Only 24 adenomas were PRL-secreting (a good response to medical treatment lead to low prevalence in surgical series).

The pathogenesis of apoplexy, an uncommon finding, is also little known. Pituitary apoplexy is defined as the sudden manifestation of symptoms such as severe headache, nausea, vomiting, loss of vision, paralysis of the cranial nerves and altered consciousness with radiologic evidence of hemorrhagic stroke in PA. ${ }^{34}$ Several neurosurgical series indicate that the incidence of pituitary apoplexy ranges from 2 to $7 \%$ when the clinical signs are associated with histopathological evidence of hemorrhage or necrosis. All kinds of gland tumors have similar risk of apoplexy. Men are more affected than women (2:1). Randeva et al. conducted a retrospective study of cases of pituitary apoplexy in order to establish the clinical presentation, predisposing factors, treatment and patient outcome. ${ }^{34}$ They concluded that the most common symptom is headache, and that HBP may be an important predisposing factor. In another similar study, also retrospective, carried out by Da Motta et al., the authors concluded that pituitary apoplexy is not an infrequent complication of adenomas. ${ }^{35}$ Only one of the 20 observed adenomas (ACTH-secreting) presented this phenomenon in a 30-year-old man with HBP.

Comparatively, primary tumors of the neurohypophysis are rare and, in general, similar to primary tumors of the central nervous system. This is confirmed in our study, which found no cancer in this part of the gland.

Two of the 25 cases of cancer in different organs and tissues (8\%) had pituitary metastases (one LL/CLL and one lung carcinoma). Other series showed similar incidence, between 2 and $25 \%,{ }^{36-38}$ although most metastatic tumors are clinically asymptomatic. It should be noted that breast and lung cancers are the most common primary neoplasms leading to metastases in the pituitary. ${ }^{39-43}$ In this study, there were only two cases of lung tumors (one of which metastasized) and no cases of breast cancer.

\section{Conclusion}

The prevalence of pituitary pathology found in our midst in this series of anatomical and clinical autopsy is similar to that described elsewhere in the world. However, contrary to what has been described in the literature, we have observed an increase in age at diagnosis. As seen in other studies, post-mortem pituitary adenomas predominate slightly among women and strongly differ from those found in surgical series regarding types of adenoma.

To our knowledge, this is the first comprehensive and updated study to estimate the prevalence of post-mortem incidental pituitary pathology conducted in Portugal.

\section{ACKNOWLEDGMENTS}

We thank Lívia Menz, Helena Simões and Gonçalo Borrecho for their constant, essential and excellent technical support. 


\section{Resumo}

Características histopatológicas de hipófises post mortem: análise retrospectiva

Objetivo: como resultado da utilização de técnicas de neuroimagem, cada vez se diagnosticam mais lesões hipofisárias silentes; porém, há poucos estudos post mortem publicados sobre essa glândula. Os dados de incidência existentes sobre lesões hipofisárias são raros, sendo em Portugal desatualizados ou inexistentes. O objetivo é determinar a prevalência dos padrões normais e da patologia hipofisária incidental post mortem no Centro Hospitalar Lisboa Norte, analisando as associações com dados clínicos e avaliando a relevância clínica dos achados.

Método: revisaram-se histologicamente de forma retrospectiva 167 hipófises de uma série consecutiva de autópsias do Serviço de Anatomia Patológica desse centro, realizadas entre 2012 e 2014, sendo revisadas em todos os casos as histórias clínicas. Os padrões morfológicos observados classificaram-se em três grandes grupos: 1) padrões histológicos de normalidade e variantes; 2) patologia infeccioso-inflamatória, distúrbios metabólicos e transtornos vasculares; 3 ) proliferação primária incidental e secundária a doenças sistêmicas.

Resultados: os doentes incluíam todas as faixas etárias (de 1 dia a 91 anos), sendo 71 do sexo feminino e 96 do masculino. Cinquenta e sete das glândulas não apresentaram qualquer alteração; 51 mostraram cistos coloides derivados da fissura de Rathke; em 44, observou-se hiperplasia da adeno-hipófise e identificaram-se 20 adenomas em 19 glândulas (oito imuno-histoquimicamente produtores de PRL e cinco de ACTH), dos quais dez associados à obesidade, 11 à hipertensão arterial e seis a diabetes mellitus. Houve dois casos com metástases.

Conclusão: a patologia subclínica em nosso meio é similar à observada em outras partes do mundo, mas em idades mais avançadas.

Palavras-chave: patologia, hipófise, autopsia.

\section{References}

1. Teramoto A, Hirakawa K, Sanno N, Osamura Y. Incidental pituitary lesions in 1000 unselected autopsy specimens. Radiology. 1994; 193(1):161-4.

2. Sanno N, Oyama K, Tahara S, Teramoto A, Kato Y. A survey of pituitary incidentaloma in Japan. Eur J Endocrinol. 2003; 149(2):123-7.

3. Vernooij MW, Ikram MA, Tanghe HL, Vincent AJ, Hofman A, Krestin GP et al. Incidental findings on brain MRI in the general population. N Engl J Med. 2007; 357(18):1821-8.

4. Ezzat S, Asa SL, Couldwell WT, Barr CE, Dodge WE, Vance ML, et al. The prevalence of pituitary adenomas: a systematic review. Cancer. 2004; 101(3):613-9.
5. Daly AF, Rixhon M, Adam C, Dempegioti A, Tichomirowa MA, Beckers A. High prevalence of pituitary adenomas: a cross-sectional study in the province of Liege, Belgium. J Clin Endocrinol Metab. 2006; 91(12):4769-75.

6. Fainstein Day P, Guitelman M, Artese R, Fiszledjer L, Chervin A, Vitale NM, et al. Retrospective multicentric study of pituitary incidentalomas. Pituitary. 2004; 7(3):145-8.

7. Sano T, Rayhan N, Yamada S. Pathology of pituitary incidentaloma. Nippon Rinsho. 2004; 62(5):940-5.

8. Hurley DM, Ho KK. MJA Practice Essentials-Endocrinology. 9: Pituitary disease in adults. Med J Aust. 2004; 180(8):419-25.

9. Kisungi S. The prevalence and classification of occult pituitary lesions at autopsy in Kenyatta National Hospital, City Mortuary and Armed Forces Memorial Hospital in Nairobi. [Dissertation]. Nairobi: Department of Human Pathology, University of Nairobi; 2010.

10. Lloyd RV, Kovacs K, Young Jr WF, Farrel WE, Asa SL, Trouillas J, et al. Tumours of the pituitary gland. In: DeLellis RA, Lloyd RV, Heitz PU, Eng $\mathrm{C}$ (eds.). Pathology and genetics of tumours of endocrine organs. WHO/ IARC Classification of Tumours. 3.ed. v.8. Lyon: IARC Press; 2004. p.9.

11. Jaffer KA, Obbens EA, El Gammal TA. "Empty" sella: review of 76 cases. South Med J. 1979; 72(3):294-6.

12. Ammar A, Al-Sultan A, Al Muhim F, Al Hassan AY. Empty sella syndrome: does it exist in children? J Neurosurg. 1999; 91(6):960-3.

13. Noronha BE, Panda NK, Mann SB, Mehra YN, Banerjee CK. Incidence of pharyngeal hypophysis in neonates: a histologic study. Ann Otol Rhinol Laryngol. 2001; 110(4):364-8.

14. Tomlinson FH, Scheithauer BW, Young WF Jr. Rathke's cleft cyst: a clinicopathologic study of 31 cases (abstract). Brain Pathol. 1994; 4:453.

15. Israel ZH, Yacoub M, Gomori JM, Dotan S, Felling Y, Shoshan Y, et al. Rathke's cleft cyst abscess. Paediatr Neurosurg. 2000; 33(3):159-61.

16. Falavigna A, Ferraz FA, Madalosso FA, Hohmann FB. Rathke's pouch cyst: case report. Arq Neuro-psiquiatr. 2003; 61(2A):281-4.

17. Rhodes RH, Davis RL, Beamer YB, Marantz C. A suprasellar epidermoid cyst with symptoms of hypothalamic involvement: case report and a review of pathogenetic mechanisms. Bull Los Angeles Neurol Soc 1981; 46:26-32.

18. Lewis AJ, Cooper PW, Kassel EE, Schwartz ML. Squamous cell carcinoma arising in a suprasellar epidermoid cyst: case report. J Neurosurg. 1983; 59(3):538-41.

19. Tomita T, Gates E. Pituitary adenomas and granular cell tumours. Incidence, cell type and location of tumour in 100 pituitary glands at autopsy. Am J Clin Pathol. 1999; 111(6):817-25.

20. Shanklin WM. Lymphocytes and lymphoid tissue in the human pituitary. Anat Rec. 1951; 111(2):177-91.

21. Leung GK, Lopesn MB, Thorner MO, Vance ML, Laws ER Jr. Primary hypophysitis: a single-center experience in 16 cases. J Neurosurg. 2004; 101(2):262-71.

22. Takao T, Nanamiya W, Matsumoto R, Asaba K, Okabayashi T, Hashimoto $\mathrm{K}$. Antipituitary antibodies in patients with lymphocytic hypophysis. Horm Res. 2001; 55(6):288-92.

23. Mooney EE, Toner M, Farrell MA. Selective necrosis of the posterior pituitary gland - case report. Clin Neuropathol. 1995; 14(1):42-4.

24. Li YN, Tao W, Ren ZY, Su CB, Wang RZ. Magnetic resonance imaging of pituitary hyperplasia in a child with growth arrest and primary hypothyroidism. Zhongguo Yi Xue Ke Xue Yuan Xue Bao. 2001; 23(4):412-4.

25. Hoogenberg K, van Tol KM. Pituitary hyperplasia during primary hypothyroidism. Thyroid. 2003; 13(8):831-2.

26. Scheithauer BW, Kovacs K, Horvath E. The adenohypophysis. In: Lechago J, Gould VE (eds.). Bloodworth's endocrine pathology. 3.ed. Baltimore: Williams and Wilkins; 1997. p.140.

27. Arrechea MA, Tuñón T, Díaz MJ, Córdoba A, Martínez-Peñuela JM. Patología hipofisaria silente. Estudio de una serie de autopsias clínicas In: IX ${ }^{\circ}$ Congreso Virtual Hispanoamericano de Anatomía Patológica y II Congreso de Preparaciones Virtuales por Internet 2007, Mayo 1-31. Conganat; 2007. [conferencia $\mathrm{N}^{\circ} 812$ ].

28. Ostrom QT, Gittleman H, Farah P, Ondracek A, Chen Y, Wolinsky Y, et al. CBTRUS statistical report: primary brain and central nervous system tumors diagnosed in the United States in 2006-2010. Neuro Oncol. 2013; 15(Suppl 2):ii1-ii56,

29. Laws ER Jr, Scheithauer BW, Groover RV. Pituitary adenomas in childhood and adolescence. Prog Exp Tumor Res. 1987; 30:359-61.

30. Auer RN, Alakija P, Sutherland GR. Asymptomatic large pituitary adenomas discovered at autopsy. Surg Neurol. 1996; 46(1):28-31. 
31. Kontogeorgos G, Kovacs K, Horvath E, Scheithauer BW. Multiple adenomas of the human pituitary. A retrospective autopsy with clinical implications. J Neurosurg. 1991; 74(2):243-7.

32. Coulon G, Fellmann D, Arbez-Gindre F, Pageaut G. [Latent pituitary adenomas. Autopsy study]. Sem Hosp. 1983; 59(40):2747-50.

33. Raappana A, Koivukangas J, Ebeling T, Pirilä T. Incidence of pituitary adenomas in Northern Finland in 1992-2007. J Clin Endocrinol Metab. 2010; 95(9):4268-75.

34. Randeva HS, Schoebel J, Byrne J, Esiri M, Adams CB, Wass JA. Classical pituitary apoplexy: clinical features, management and outcome. Clin Endocrinol (Oxf). 1999; 51(2):181-8.

35. da Motta LA, de Mello PA, de Lacerda CM, Neto AP, da Motta LD, Filho MP. Pituitary apoplexy. Clinical course, endocrine evaluations and treatment analysis. J Neurosurg Sci. 1999; 43(1):25-36.

36. Teears RJ, Silverman EM. Clinicopathologic review of 88 cases of carcinoma metastatic to the pituitary gland. Cancer. 1975; 36(1):216-20.
37. Megan Ogilvie C, Payne S, Evanson J, Lister TA, Grossman AB. Lymphoma metastasizing to the pituitary: an unusual presentation of a treatable disease. Pituitary. 2005; 8(2):139-46.

38. Heshmati HM, Scheithauer BW, Young WF Jr. Metastases to the pituitary gland. Endocrinologist. 2002; 12(1):45-9.

39. Komninos J, Vlassopoulou V, Protopapa D, Korfias S, Kontogeorgos G Sakas DE, et al. Tumors metastatic to the pituitary gland: case report and literature review. J Clin Endocrinol Metab. 2004; 89(2):574-80.

40. Coutinho L, Furian R. Metástase de carcinoma de mama na hipófise: relato de um caso. Arq Neuro-Psiquiatr. 1978; 36(4):365-70.

41. Marin F, Kovacs KT, Scheithauer BW, Young WF Jr. The pituitary gland in patients with breast carcinoma: a histologic and immunocytochemical study of 125 cases. Mayo Clin Proc. 1992; 67(10):949-56.

42. de la Monte SM, Hutchins GM, Moore GW. Endocrine organ metastases from breast carcinoma. Am J Pathol. 1984; 114(1):131-6.

43. Struk DW, Knapp TR, Munk PL, Poon PY. Pituitary and intradural spinal metastases: an unusual initial presentation of lung cancer. Can Assoc Radiol J. 1995; 46(2):118-21. 